\title{
Effects of Aging on Nicotinic and Muscarinic Autoreceptor Function in the Rat Brain: Relationship to Presynaptic Cholinergic Markers and Binding Sites
}

\author{
Dalia M. Araujo, ${ }^{1}$ Paul A. Lapchak, ${ }^{2}$ Michael J. Meaney, ${ }^{1}$ Brian Collier, ${ }^{2}$ and Remi Quirion ${ }^{1,2}$ \\ 'Douglas Hospital Research Center and Department of Psychiatry and 2Department of Pharmacology and Therapeutics, \\ McGill University, Montreal, Quebec, Canada H4H 1R3
}

The main objectlve of the present work was to determine whether the regulation of $\mathrm{ACh}$ release by nicotinic and muscarinic autoreceptors is compromised in the aged rat brain. For this, the effects of the nicotinic agonist $\mathrm{N}$-methylcarbamylcholine (MCC) and the muscarinic- $M_{2}$ antagonist AFDX 116 on ACh release from brain slices of young (3-monthold), adult (9-month-old), and aged (27-month-old) rats were tested. The ability of MCC to enhance spontaneous ACh release in hippocampal, cerebral cortical, and cerebellar slices was only modestly altered with age. In contrast, the sensitivity of muscarinic autoreceptors in the aged hippocampus and cerebral cortex, but not the striatum, to blockade by the muscarinic- $M_{2}$ antagonist AF-DX 116 was severely attenuated.

To assess whether the age-related changes in cholinergic autoreceptor function may be due to deficits in presynaptic cholinergic markers, we tested whether choline acetyltransferase (ChAT) activity, basal and evoked $A C h$ release, and nicotinic and muscarinic binding sites are altered in the aged rats. ChAT activity in forebrain regions was decreased in the aged compared to the young and mature adult rats. Furthermore, the potassium-evoked, but not the spontaneous, release of ACh was markedly depressed in striatal, hippocampal, and cortical slices of aged rats. The densities of nicotinic and muscarinic- $M_{2}$ binding sites, assessed using ${ }^{3} \mathrm{H}-\mathrm{MCC}$ and ${ }^{3} \mathrm{H}-A F-D X 116$ as selective ligands, respectively, were markedly reduced in homogenates of the striatum, hippocampus, cerebral cortex, and thalamus of aged rats. In contrast, muscarinic- $M_{1}$ sites, selectively labeled with ${ }^{3} \mathrm{H}$ pirenzepine, were not affected. Therefore, it appears that age-related decrements in ChAT activity and in muscarinic$M_{2}$, but not nicotinic, binding sites in the rat brain are reflected in a decreased functlon of muscarinic- $M_{2}$ autoreceptors. However, the positive correlation between loss of ChAT activity, decreased muscarinic- $M_{2}$ binding sites, and impaired muscarinic autoreceptor function is clearly tissue dependent.

Received Jan. 17, 1990; revised Mar. 29, 1990; accepted May 1, 1990.

This work was supported by the Medical Research Council of Canada. R.Q. is a "Chercheur-Boursier" and D.M.A. and P.A.L. are postdoctoral fellows of the Fonds de Recherche en Sante du Quebec. M.J.M. is a University Research Fellow of the Natural Sciences and Engineering Research Council of Canada.

Correspondence should be addressed to Remi Quirion, Douglas Hospital Research Center, Heinz Lehmann Pavilion, 6875 Lasalle Boulevard, Verdun, Quebec, Canada H4H 1R3

Copyright (C) 1990 Society for Neuroscience $0270-6474 / 90 / 093069-10 \$ 03.00 / 0$
Evidence from measures on human and animal tissues indicates that deficits in pre- and postsynaptic neurochemical markers are prominent in the brain in response to aging and age-rclatcd disorders (see reviews by Candy et al., 1986; Decker, 1987). Because dysfunctions of cortical and hippocampal cholinergic processes in Alzheimer's disease appear to be associated with severe memory impairments (see Bartus et al., 1982), particular emphasis has been placed on the study of $\mathrm{ACh}$ in the aged brain. Recent studies have demonstrated that the stimulated release of $\mathrm{ACh}$ is compromised in the aged rat brain (Pedata et al., 1983, 1985; Meyer et al., 1984, 1986; Vannucchi and Pepeu, 1987; Takei et al., 1989). However, whether this reduction in $\mathrm{ACh}$ release is consequent to a change in cholinergic autoreceptor function has not been extensively studied.

Several studies have demonstrated age-related decrements in ChAT activity (Dravid, 1983; Pintor et al., 1988; Michalek et al., 1989; Waller and London, 1989), depolarization-induced ACh release (Pedata et al., 1983, 1985; Meyer et al., 1984, 1986; Vannucchi and Pepeu, 1987; Takei et al., 1989), and muscarinic binding site density (Gurwitz et al., 1987; Surichamorn et al., 1988; Michalek et al., 1989; Waller and London, 1989) in the aged rodent brain. However, results showing insignificant agerelated changes in ChAT activity (Meek et al., 1977; Strong et al., 1980, 1986; London et al., 1985; Norman et al., 1986), ACh release (Sims et al., 1982), and muscarinic binding sites (Morin and Wasterlain, 1980; Springer et al., 1987) have also been reported. In contrast, studies on the status of nicotinic binding sites in animal models of aging have not been previously documented.

Therefore, the main goal of the present experiments was to determine whether nicotinic and muscarinic autoreceptor regulation of $\mathrm{ACh}$ release in the rat brain is altered with age. For this, we tested the sensitivity of various brain regions in young and old rats to ${ }^{3} \mathrm{H}-\mathrm{N}$-methylcarbamylcholine (MCC) and 11 2-[[2-[(diethylamino)methyl]-1-piperidinyl]acetyl]5,11-dihydro6H-pyrido[2,3-b][1,4] benzodiazepin-6-1 (AF-DX 116) drugs known to enhance $\mathrm{ACh}$ release from tissue slices of young rats (Araujo et al., 1988b; Lapchak et al., 1989a, b, c). In view of the conflicting evidence about age-related changes in presynaptic cholinergic markers, we tested whether various cholinergic markers are reduced in the aged rat brain. First, we assessed whether aging affects cholinergic binding sites in the rat brain by using ${ }^{3} \mathrm{H}-\mathrm{MCC},{ }^{3} \mathrm{H}-\mathrm{AF}$-DX 116 , and ${ }^{3} \mathrm{H}$-pirenzepine to selectively label nicotinic and muscarinic- $\mathbf{M}_{2}$ and $-\mathbf{M}_{1}$ sites, respectively. Second, we measured $\mathrm{ChAT}$ activity and $\mathrm{ACh}$ release in various regions of young (3-month-old), adult (9-month-old), 
and aged (27-month-old) rats. The results demonstrate that aging provokes marked alterations in muscarinic, but not nicotinic, autoreceptor function in the hippocampus and cerebral cortex and significant reductions in presynaptic cholinergic markers in all forebrain regions studied.

\section{Materials and Methods}

Materials. Young (2-month-old) male Long-Evans rats were purchased from Charles River Breeding Farms (St. Constant, Quebec) and maintained in temperature-controlled animal quarters, with food and water ad libitum, for $1-25$ months. ${ }^{3} \mathrm{H}-\mathrm{MCC}(86.6 \mathrm{Ci} / \mathrm{mmol}),{ }^{3} \mathrm{H}$-pirenzepine $(72 \mathrm{Ci} / \mathrm{mmol}),{ }^{3} \mathrm{H}$-AF-DX $116(62-81 \mathrm{Ci} / \mathrm{mmol}),{ }^{32} \mathrm{P}-\mathrm{ATP}(2-10 \mathrm{Ci} /$ $\mathrm{mmol})$, and ${ }^{14} \mathrm{C}$-acetyl coenzyme $\mathrm{A}(50-60 \mathrm{Ci} / \mathrm{mol})$ were obtained from New England Nuclear (Boston, MA). Physostigmine sulfate, choline chloride, atropine sulfate, choline kinase (EC 2.7.1.32, ATP: choline phosphotransferase), ACh esterase (EC 3.1.1.7, ACh hydrolase, type V-S) were from Sigma Chemical Co. (St. Louis, MO). Tetraphenylboron (TPB), sodium salt, and butyronitrile were obtained from Aldrich Chemical Co. (Milwaukee, WI); 3-heptanone was from Eastman Kodak Co. (Rochester, NY). ACh chloride was from Hoffman-La Roche (Basel, Switzerland). Unlabeled MCC and AF-DX 116 were generous gifts from Dr. Leo Abood (Rochester, NY) and Dr. Karl Thomae GmbH (Biberach an der Riss, FRG), respectively. All other chemicals were from Fisher Scientific Co. (Montreal, CAN).

Preparation and incubation of tissue slices for measures of ACh release. Brain slices were prepared as described previously (Araujo et al., 1988b; Lapchak et al., 1989a, b, c). Rats (3-, 9-, and 27-month-old) were decapitated, and their brains were rapidly removed into ice-cold Krebs medium (composition, in mM: $\mathrm{NaCl}, 120 ; \mathrm{KCl}, 4.6 ; \mathrm{CaCl}_{2}, 2.4 ; \mathrm{KH}_{2} \mathrm{PO}_{4}$, 1.2; $\mathrm{MgSO}_{4}, 1.2$; glucose, 9.9; $\mathrm{NaHCO}_{3}, 25$ ); this was equilibrated with $5 \% \mathrm{CO}_{2}$ in $\mathrm{O}_{2}$ to maintain a pH of 7.4 at $37^{\circ} \mathrm{C}$. Then, hippocampi, frontal cortices, striata, and cerebella from each age group were dissected and sliced using a Mcllwain tissue chopper (set at $0.2 \mathrm{~mm}$ thickness). Slices (30-105 mg tissue) were preincubated in normal Krebs medium $(0.5 \mathrm{ml})$ containing physostigmine sulfate $(30 \mu \mathrm{M})$ and choline chloride $(10 \mu \mathrm{M})$ for a recovery period of $60 \mathrm{~min}$, with 1 change of medium. Media were separated from tissue slices by centrifugation in a microfuge. For a measure of evoked $\mathrm{ACh}$ release from slices, tissues were incubated in Krebs medium containing a depolarizing concentration of $\mathrm{K}^{+}(25$ mM), with equimolar reduction of $\mathrm{NaCl}$.

In experiments that tested the effects of MCC on ACh release, tissues (hippocampi, frontal cortices, and cerebella) were first incubated in normal Krebs medium for $10 \mathrm{~min}$, and media were collected for a measure of basal ACh release, after which slices were incubated in the same medium containing various $(0.1-100 \mu \mathrm{M})$ concentrations of MCC. In an additional set of experiments that tested the effects of MCC on evoked ACh release, hippocampal and cerebral cortical slices from 3-monthold rats were first incubated $(10 \mathrm{~min})$ in normal Krebs medium, followed by a 10-min incubation in $25 \mathrm{~mm} \mathrm{~K} \mathrm{~K}^{+} \mathrm{Krebs}$ medium (S1); media were collected for a measure of basal and evoked ACh release, respectively. Slices were reincubated in normal Krebs medium for a 10 -min washout period. Following this, cortices were exposed first to normal Krebs medium $(10 \mathrm{~min})$ and then to $25 \mathrm{~mm} \mathrm{~K}^{+} \mathrm{Krebs}$ medium $(10 \mathrm{~min})$ containing $\mathrm{MCC}(0.1-100 \mu \mathrm{M})(\mathrm{S} 2)$. In experiments that tested the effects of AF-DX 116 on ACh release, tissues (hippocampi, frontal cortices, and striata) were similarly incubated, but for 20 -min periods, with a 30 -min washout period prior to incubations with various concentrations $(0.1-100 \mu \mathrm{M})$ of the drug. For each tissue, only 1 concentration of the drug was tested. Viability of the tissue slices was verified by comparing the release of ACh during S2 to that in S1. In the aged (27-month-old) rats, the ratio of $S 2: S 1$ was not lower than 0.71 in striata and 0.86 in hippocampi and cerebral cortices.

For each rat, MCC was tested in one tissue, while AF-DX 116 was tested in the corresponding contralateral tissue. In all cases, the incubation medium contained choline chloride $(10 \mu \mathrm{M})$ to support ACh synthesis and physostigmine sulfate $(30 \mu \mathrm{M})$ to allow collection of $\mathrm{ACh}$. $\mathrm{ACh}$ release in slices incubated without drug represents control $(100 \%)$ release; $\mathrm{ACh}$ release in the presence of drug is expressed as a percent of this value.

Assay of $A C h$. ACh release from slices of rat brain tissue was determined by the radioenzymic assay of Goldberg and McCaman (1973), as described by Araujo et al. (1988b). ACh was extracted from media in which slices were incubated by adding an equal volume of TPB in butyronitrile $(10 \mathrm{mg} / \mathrm{ml})$. Samples were shaken and centrifuged in a microfuge. ACh was recovered from the organic (top) phase by shaking with a half volume of $\mathrm{AgNO}_{3}(0.12 \mathrm{M})$, as described by Fonnum (1969a). Excess silver was precipitated by the addition of $20 \mu \mathrm{l} \mathrm{MgCl}(\mathrm{l} \mathrm{M})$ per sample. Samples were then lyophilized and redissolved in $32 \mu \mathrm{l}$ of a reaction medium containing ATP $(0.8 \mathrm{~mm})$, dithiothreitol $(5 \mathrm{~mm}), \mathrm{MgCl}_{2}$ (12.5 mM), glycylglycine ( $25 \mathrm{~mm} ; \mathrm{pH}, 8.3)$, and choline kinase $(0.005$ $\mathrm{U}$ ). These samples were incubated at $30^{\circ} \mathrm{C}$ for $45 \mathrm{~min}$ to phosphorylate the endogenous choline in the samples. Following this, a solution (10 $\mu$ ) containing AChE ( $2 \mathrm{U}$ ) and ${ }^{32} \mathrm{P}-\mathrm{ATP}$ (approximately $0.75 \mu \mathrm{Ci}$ ) was added to each sample, which was then reincubated for $45 \mathrm{~min}$ at $30^{\circ} \mathrm{C}$. During this second incubation, sample $A C h$ was hydrolyzed, and the choline thus formed was phosphorylated to ${ }^{32} \mathrm{P}$-phosphorylcholine. After the reaction was terminated by the addition of $300 \mu$ lice-cold $\mathrm{NaOH}$ ( $50 \mathrm{~mm}$ ), radioactive phosphorylcholine was separated from unchanged ${ }^{32} \mathrm{P}-\mathrm{ATP}$ by ion-exchange chromatography on Amberlite CG-400 (converted to formate form) columns, which had been equilibrated $(\mathrm{pH}$, 12.0) previously with $\mathrm{NaOH}(50 \mathrm{~mm})$. Phosphorylcholine was eluted with $2.5 \mathrm{ml}$ of $\mathrm{NaOH}(50 \mathrm{~mm}$ ). For each experiment, standard amounts of ACh dissolved in the same medium as the test samples were extracted and assayed along with the test samples.

Assay for ChAT activity. ChAT activity in various tissues of the rat brain was determined by the method of Fonnum $(1969 \mathrm{~b})$, as modified by Tuček (1978). Tissues were homogenized in a medium of the following composition: $\mathrm{NaCl}(200 \mathrm{~mm})$, sodium phosphate buffer $(\mathrm{pH}, 7.4$; $40 \mathrm{~mm}$ ); Triton X-100 $(0.5 \%)$. Samples $(35 \mu \mathrm{l})$ were then incubated $\left(38^{\circ} \mathrm{C}, 30 \mathrm{~min}\right)$ in a medium $(15 \mu \mathrm{l})$ containing unlabeled acetyl $\mathrm{CoA}$ and ${ }^{14} \mathrm{C}$-acetyl $\mathrm{CoA}$ (for a final concentration of $0.25 \mathrm{~mm}$ acetyl $\mathrm{CoA}$ ), choline chloride (12.5 mM), physostigmine sulfate $(0.2 \mathrm{~mm}), \mathrm{NaCl}(300$ $\mathrm{mm}$ ), Na-phosphate buffer ( $\mathrm{pH}, 7.4 ; 28 \mathrm{~mm}$ ), bovine serum albumin $(0.5 \mathrm{mg} / \mathrm{ml})$, and Triton $\mathrm{X}-100(0.35 \%)$. The reaction was terminated by the addition of TPB/heptanone $(15 \mathrm{mg} / \mathrm{ml})$, which extracts the ${ }^{14} \mathrm{C}$ $\mathrm{ACh}$, but not the ${ }^{14} \mathrm{C}$-acetyl-CoA. Radioactivity in the top organic phase was determined by liquid scintillation spectrometry.

Binding of ${ }^{3} \mathrm{H}-\mathrm{MCC}$ to brain nicotinic sites. Membrane-enriched homogenates were prepared from rat brain tissues, and ${ }^{3} \mathrm{H}-\mathrm{MCC}$ binding was measured under equilibrium conditions, as described previously (Araujo et al., 1988b; Lapchak et al., 1989a, b). Hippocampi, cerebral cortices, striata, cerebella, and thalami from young (3-month-old), adult (9-month-old) and old (27-month-old) rats were dissected from brains and homogenized with a Brinkmann Polytron (setting 6, $20 \mathrm{sec}$ ) in buffer of the following composition (in $\mathrm{mm}$ ): Tris- $\mathrm{HCl}, 50 ; \mathrm{NaCl}, 120 ; \mathrm{KCl}$, 5; $\mathrm{CaCl}_{2}, 2 ; \mathrm{MgCl}_{2}, 1(\mathrm{pH}, 7.4)$. Homogenates were centrifuged for 10 min at $49,000 \times g$, after which supernatants were discarded and the pellets washed twice by resuspending in fresh buffer and recentrifuging. The final membrane pellets were suspended in buffer. Aliquots of homogenate (100-300 $\mu$ g protein) were incubated in buffer (composition as above) with various concentrations of ${ }^{3} \mathrm{H}-\mathrm{MCC}(0.1-30 \mathrm{nM})$ for 60 min at $4^{\circ} \mathrm{C}$ in a total vol of $0.5 \mathrm{ml}$. Bound ${ }^{3} \mathrm{H}-\mathrm{MCC}$ was separated from free ligand by rapid filtration under reduced pressure using a Brandel Cell Harvester apparatus (Gaithersburg, MD) through GF/B filters presoaked in $0.5 \%$ polyethyleneimine to reduce binding to filters. Filters were washed rapidly with ice-cold Tris- $\mathrm{HCl}(50 \mathrm{~mm})$ buffer $(4 \times 4 \mathrm{ml})$. Specific binding was calculated as the difference in radioactivity bound in the absence and in the presence of $10 \mu \mathrm{M}$ nicotine; this represented $60 \%$ of the total binding at concentrations approximating the $K_{d}$ value.

Binding of ${ }^{s} H$-pirenzepine to brain muscarinic- $M$, sites. ${ }^{3} \mathrm{H}$-Pirenzepine binding was measured under conditions where equilibrium binding was achieved (see Lapchak et al., 1989c). Tissues were homogenized in Krebs buffer of the following composition (in $\mathrm{mm}$ ): $\mathrm{NaCl}, 120$; $\mathrm{Mg}$ $\mathrm{SO}_{4} .7 \mathrm{H}_{2} \mathrm{O}, 1.2 ; \mathrm{KH}_{2} \mathrm{PO}_{4}, 1.2$; glucose, 5.6; $\mathrm{NaHCO}_{3}, 25 ; \mathrm{CaCl}_{2}, 2.5$; $\mathrm{KCl}, 4.7$ ( $\mathrm{pH}, 7.4$ ). Aliquots of the final membrane pellets were incubated in Krebs buffer with various concentrations of ${ }^{3} \mathrm{H}$-pirenzepine (0.1-50 nM) for $60 \mathrm{~min}$ at $22^{\circ} \mathrm{C}$. Termination of binding assays was as described above for ${ }^{3} \mathrm{H}$-MCC binding. Specific binding was defined in the presence of $1 \mu \mathrm{M}$ atropine sulfate and represented $85-88 \%$ of the total binding at concentrations close to the $K_{d}$.

Binding of ${ }^{3} \mathrm{H}-A F-D X 116$ to brain muscarinic $M$, sites. ${ }^{3} \mathrm{H}-\mathrm{AF}-\mathrm{DX}$ 116 binding was measured under conditions where equilibrium binding was achieved as described previously (Araujo et al., 1989; Lapchak et al., 1989c). Membranes were prepared as described for ${ }^{3} \mathrm{H}$-pirenzepine binding above. Aliquots of the final membrane pellets $(200-400 \mu \mathrm{g})$ were incubated in Krebs buffer containing various concentrations of ${ }^{3} \mathrm{H}-$ AF-DX $116(2-100 \mathrm{~nm})$ for $60 \mathrm{~min}$ at $4^{\circ} \mathrm{C}$. Bound ${ }^{3} \mathrm{H}-\mathrm{AF}-\mathrm{DX} 116$ was separated from free by rapid filtration as described above. Specific bind- 
ing was calculated as the difference in radioactivity bound in the absence and in the presence of $1 \mu \mathrm{M}$ atropine sulfate; this represented approximately $55 \%$ of the total binding at concentrations close to the $K_{d}$ value.

Protein assays. Protein was measured by the method of Lowry et al. (1951), using bovine serum albumin as a standard. Tissue samples were dissolved in $1 \mathrm{M} \mathrm{NaOH}$ at $70^{\circ} \mathrm{C}$ for $30 \mathrm{~min}$.

Analysis of binding data. All binding data were derived from the saturation experiments for ${ }^{3} \mathrm{H}-\mathrm{MCC},{ }^{3} \mathrm{H}$-pirenzepine, and ${ }^{3} \mathrm{H}-\mathrm{AF}-\mathrm{DX}$ 116. Values for the $K_{d}$ and $B_{\max }$ were obtained by computerized analysis using LIGAND by Munson and Rodbard (1980), as modified by G. A. McPherson (Elsevier Biosoft, 1985).

Determination of radioactivity. Radioactivity was detcrmincd by liquid scintillation spectrometry using Scintiverse 2 as the solvent. Efficiencies of counting were approximately $100 \%$ for ${ }^{32} \mathrm{P}$ (ACh assay), $85 \%$ for ${ }^{14} \mathrm{C}$ (ChAT assay), and $40 \%$ for ${ }^{3} \mathrm{H}$ (binding assays for MCC, pirenzepine, AF-DX 116).

Statistical analyses. Results are expressed as means \pm SEM of the number of experiments indicated. ACh release in brain slices incubated in the presence of a drug was compared to that measured in a preceding incubation period, during which the same tissue slices were exposed to the same medium, but without any drug. Thus, each experimental value could be compared to its own individual control value for the same tissue. Therefore, statistical significance was determined using Student's paired $t$ test, by comparing ACh release in the presence of a drug to that in its absence (control). Statistical differences in cholinergic parameters for the older (9- and 27-month-old) rats compared to the young (3month-old) rats were assessed using Student's unpaired $t$ test, after oneway analysis of variance (ANOVA). Thus, the drug effects on ACh release (expressed as percent control), the basal and evoked release of $\mathrm{ACh}$ in the absence of drugs, and the activity of ChAT in the aged animals were compared to the values obtained for the corresponding tissue in the young (3-month-old) group.

\section{Results}

Effects of aging on cholinergic nicotinic autoreceptor function and nicotinic binding sites in the rat brain

Nicotinic autoreceptor function. To determine if nicotinic autoreceptor function is altered in the aged rat brain, we tested the effects of unlabeled $\mathrm{MCC}$ on spontaneous $\mathrm{ACh}$ release from tissue slices. In previous studies, we showed that MCC increases spontaneous $\mathrm{ACh}$ release in hippocampal, frontal cortical, and cerebellar, but not striatal, slices of young Sprague-Dawley rats by activating presynaptic nicotinic receptors (Araujo et al., 1988b; Lapchak et al., 1989a, b). Furthermore, the potassium-evoked release of $\mathrm{ACh}$ in these tissues was found to be unaffected by MCC. However, in view of certain species and strain differences in cholinergic parameters that have been observed in aged rodents (Gilad and Gilad, 1987; Michalek et al., 1989), the present experiments first verified whether $\mathrm{MCC}$ also enhances $\mathrm{ACh}$ release in brain slices of Long-Evans rats. The results confirm that $\mathrm{MCC}$ increases spontaneous $\mathrm{ACh}$ release from slices of cerebellum (Fig. 1 $A$ ), hippocampus (Fig. $1 B$ ), and frontal cortex (Fig. $1 C$ ) of young (3-month-old) rats. Moreover, release from striatal slices was not affected (103.4 $\pm 5.6 \%$ control) by the drug. In addition, the potassium (25 mM)-evoked release of $\mathrm{ACh}$ from cortical slices of young rats was not augmented by MCC (range, 93-106\% control).

As shown in Figure 1, in the young (3-month-old) rats, $10^{-6}$ and $10^{5} \mathrm{M} \mathrm{MCC}$ significantly augmented $\mathrm{ACh}$ release (Fig. 1). This increase ranged from 43 to 74 percent of control (release without drug). With the exception of the hippocampus, no significant modifications of the MCC-induced increase in $\mathrm{ACh}$ release were apparent in the 9-month-old rats (Fig. 1). In these animals, the ability of MCC to increase ACh release from hippocampal slices was apparent only at higher concentrations of drug $\left(10^{-5}, 10^{-4} \mathrm{M}\right.$; Fig. $\left.1 \mathrm{~B}\right)$. Similarly, in the 27 -month-old group, the concentrations of $\mathrm{MCC}$ required to enhance $\mathrm{ACh}$

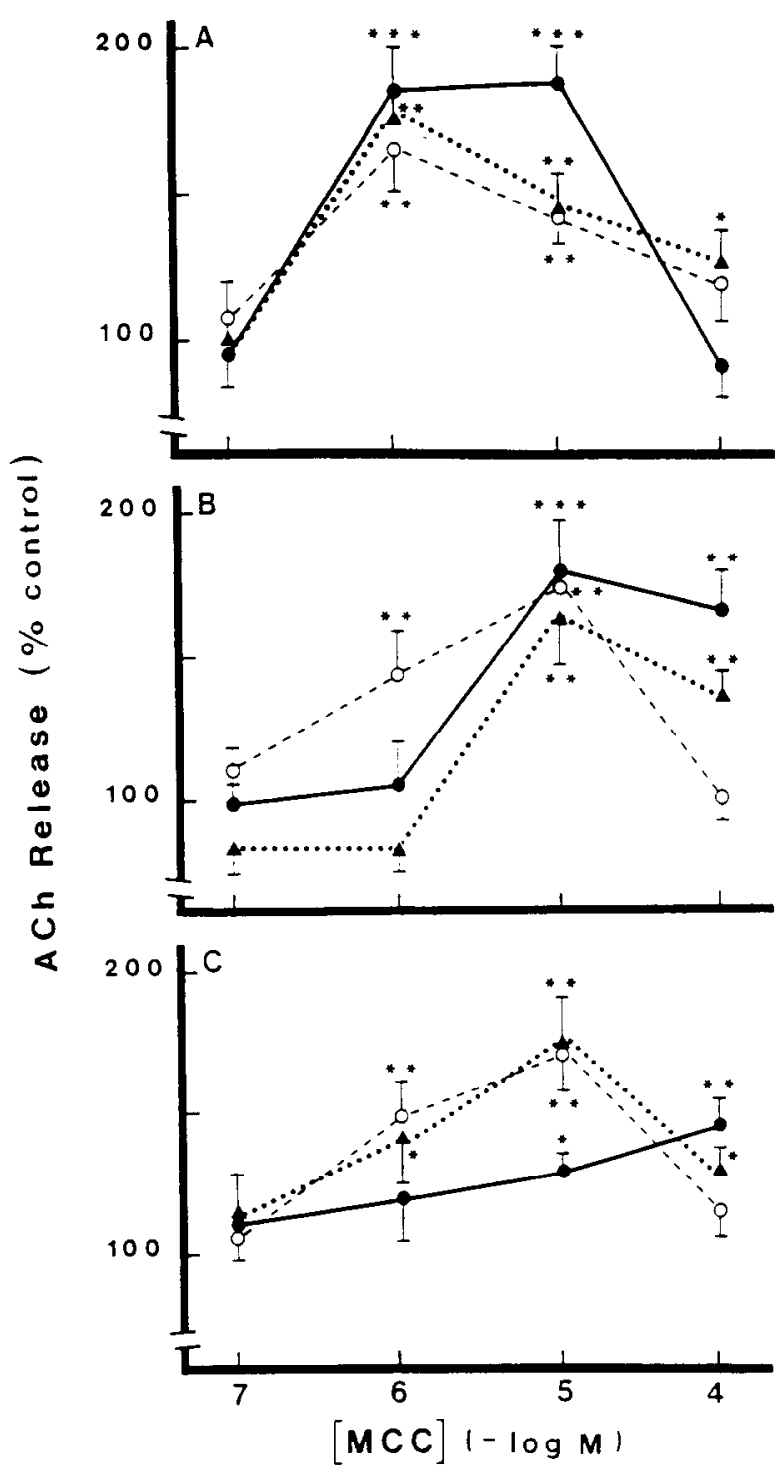

Figure 1. Effects of the nicotinic agonist MCC on spontaneous release of endogenous $\mathrm{ACh}$ from brain slices of young (3-month-old; open circles), adult (9-month-old; solid triangles), and old (27-month-old; solid circles) rats. Cerebellar $(A)$, hippocampal $(B)$, or frontal cortical $(C)$ slices were incubated in normal-potassium Krebs medium in the presence or absence (control) of various concentrations of MCC. Results are expressed as percent control (release in the absence of drug measured during a preceding incubation period) and are the means \pm SEM of 4 5 experiments for each concentration of drug tested. The overall control (no drug) value (100\%) for basal ACh release from brain slices of young rats was $0.20 \pm 0.07,1.58 \pm 0.15$, and $1.39 \pm 0.10 \mathrm{pmol} / \mathrm{mg}$ tissue/ $10 \mathrm{~min}$ for the cerebellum, hippocampus, and frontal cortex, respectively. ${ }^{*}, p<0.05 ;{ }^{* *}, p<0.01 ; * * *, p<0.001$; compared to release for the same tissue, but in the absence of drug.

release $\left(10^{-5}, 10^{-4} \mathrm{M}\right)$ in hippocampal (Fig. $\left.1 B\right)$ and frontal cortical (Fig. 1C) slices were higher than for the 3-month-old rats. In contrast, there was no apparent shift in concentration of the MCC effect in the cerebellum of the aged rats (Fig. 1 $A$ ).

Nicotinic binding sites. To test whether the density or affinity of nicotinic binding sites is altered in the aged, compared to the young rats, ${ }^{3} \mathrm{H}-\mathrm{MCC}$ binding was measured in various brain regions. As described previously, ${ }^{3} \mathrm{H}-\mathrm{MCC}$ bound specifically, saturably, and with high affinity to brain nicotinic sites (Abood and Grassi, 1986; Boksa and Quirion, 1987; Araujo et al., 1988a, 
Table 1. Parameters of ${ }^{3} \mathrm{H}-\mathrm{MCC} /$ /nicotinic binding in the rat brain

\begin{tabular}{lccc}
\multicolumn{4}{l}{3 H-MCC binding } \\
\cline { 2 - 3 } & 3 -month-old & 9 -month-old & 27 -month-old \\
\hline Cerebral cortex & & & \\
$B_{\max }$ & $34.3 \pm 3.8$ & $24.1 \pm 3.1^{*}$ & $20.1 \pm 4.6^{* *}$ \\
$K_{d}$ & $9 \pm 2$ & $12 \pm 3$ & $9 \pm 2$ \\
Striatum & & & \\
$B_{\max }$ & $29.9 \pm 4.2$ & $27.3 \pm 4.8$ & $13.3 \pm 2.1^{* * *}$ \\
$K_{d}$ & $8 \pm 2$ & $11 \pm 2$ & $7 \pm 1$ \\
Hippocampus & & & \\
$B_{\max }$ & $18.7 \pm 2.5$ & $18.1 \pm 3.4$ & $12.3 \pm 2^{* *}$ \\
$K_{d}$ & $6 \pm 1$ & $8 \pm 2$ & $8 \pm 1$ \\
Thalamus & & & \\
$B_{\max }$ & $51.3 \pm 9.4$ & $49.1 \pm 1.5$ & $40.3 \pm 7.3$ \\
$K_{d}$ & $10 \pm 2$ & $8 \pm 1$ & $8 \pm 2$ \\
Cerebellum & & & $9.7 \pm 2.4$ \\
$B_{\max }$ & $9.1 \pm 1.6$ & $10.7 \pm 1.1$ & $3 \pm 1$ \\
$K_{d}$ & $5 \pm 1$ & $4 \pm 1$ &
\end{tabular}

Binding data were derived from full saturation analysis. Brain homogenates from 3-, 9-, and 27-month-old rats were prepared as described in the text and incubated in buffer containing various concentrations of ${ }^{3} \mathrm{H}-\mathrm{MCC}(1-30 \mathrm{nM})$ for $60 \mathrm{~min}$ at $4^{\circ} \mathrm{C} . B_{\max }$ is the maximal binding capacity $\left(10^{-15} \mathrm{~mol} / \mathrm{mg}\right.$ protein), and $K_{d}$ is the apparent affinity of binding (nM). Values are the mean \pm SEM of $4-5$ experiments; each concentration was tested in triplicate

${ }^{*}, p<0.05 ;{ }^{* *}, p<0.01 ;{ }^{* * *}, p<0.001$; compared to 3-month-old group.

b; Lapchak et al., 1989a, b). The only apparent difference in ${ }^{3} \mathrm{H}$ MCC binding parameters between the 3- and 9-month-old rats was a reduction $(29.7 \%)$ in the density $\left(B_{\max }\right)$ of ${ }^{3} \mathrm{H}-\mathrm{MCC}$ sites in the cerebral cortex (Table 1). Binding was not affected in the other brain regions tested (Table 1). In the 27-month-old rats, a decrease of similar magnitude in the density of cortical ${ }^{3} \mathrm{H}$ MCC binding sites was measured (Table 1). In addition, significant reductions (34-56\%) in site densities were found in other forebrain regions (striatum, hippocampus) of the old, compared to the young rats, but not in the cerebellum or thalamus (Table 1). The decrease in ${ }^{3} \mathrm{H}-\mathrm{MCC}$ binding sites was the result of a reduction in the $B_{\max }$ and not due to an alteration in the affinity of binding, because there were no differences in the $K_{d}$ value for the corresponding tissue in the 3 age groups (Table 1 ).

\section{Effects of aging on cholinergic muscarinic autoreceptor function and muscarinic binding sites in the rat brain}

Muscarinic autoreceptor function. To determine whether muscarinic- $\mathrm{M}_{2}$ autoreceptor function is affected in the aged rat brain, we tested the effects of unlabeled AF-DX 116 on ACh release from tissue slices. As described previously, AF-DX 116 significantly enhances the evoked, but not the spontaneous, release of ACh from several forebrain tissues in young Sprague-Dawley rats (Lapchak et al., 1989c). The present experiments demonstrate that AF-DX 116 also augments $A C h$ release in striatal (Fig. 2A), hippocampal (Fig. 2B), and frontal cortical (Fig. 2C) slices from young (3-month-old) Long-Evans rats; this increase ranged between $20-46 \%$ compared to control (release in the absence of drug). Because an earlier study demonstrated that muscarinic autoreceptor regulation of $\mathrm{ACh}$ release is not evident in slices of cerebellum (Lapchak et al., 1989b), effects of AFDX 116 in this tissue were not tested.

In the 9-month-old group, the ability of AF-DX 116 to enhance evoked $\mathrm{ACh}$ release from slices was not significantly dif-

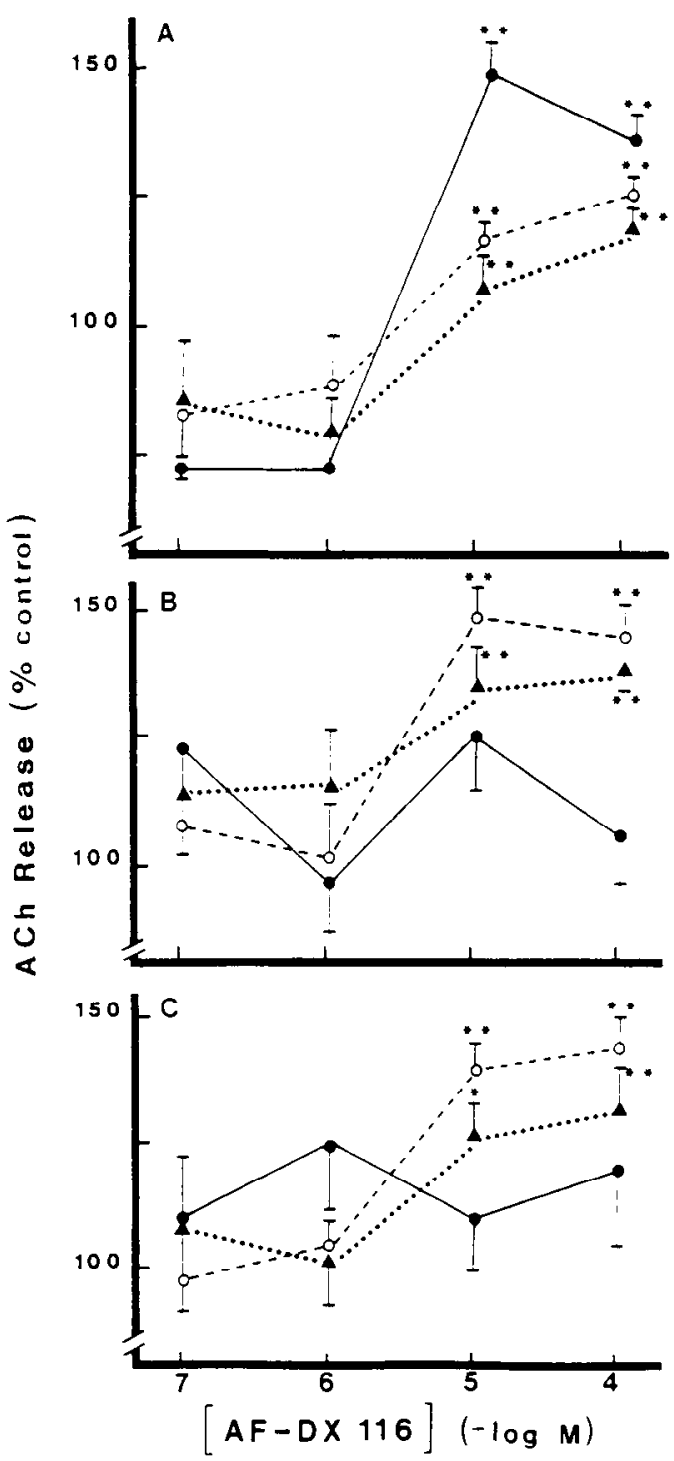

Figure 2. Effects of muscarinic antagonist AF-DX 116 on $\mathrm{K}^{+}(25 \mathrm{~mm})-$ evoked release of $\mathrm{ACh}$ endogenous from brain slices of 3- (open circles), 9- (solid triangles) and 27- (solid circles) month-old rats. Striatal $(A)$, hippocampal $(B)$, or frontal cortical $(C)$ slices were depolarized with Krebs medium containing $25 \mathrm{~mm}$ potassium, in the presence or absence (control) of various concentrations of AF-DX 116. Results are expressed as percent control, that is, release in the absence of drug measured during a preceding incubation period in the same tissue, and are the means \pm SEM of 4-5 experiments for each concentration of drug tested. The overall control (no drug) value (100\%) for evoked ACh relcase from brain slices of 3 -month-old rats was $15.6 \pm 1.2,8.7 \pm 0.9$, and $4.7 \pm$ $0.7 \mathrm{pmol} / \mathrm{mg}$ tissue $/ 20 \mathrm{~min}$ for the striatum, hippocampus, and frontal cortex, respectively. The ratio of $\mathbf{S} 2: \mathrm{S} 1$ ranged between 0.86 and 1.23 for hippocampal and frontal cortical slices of aged (27-month-old) rats. ${ }^{*}, p<0.05 ;{ }^{* *}, p<0.01$; compared to release in the absence of drug.

ferent from that in the 3-month-old rats (Fig. 2). In the 3 brain regions tested, the maximal increases in $\mathrm{ACh}$ release induced by AF-DX 116 were similar in the 2 groups of younger rats (Fig. 2 ). In contrast, several differences in the AF-DX 116 effect in the aged rats are apparent. In striatal slices, the effect of AFDX 116 is slightly elevated in the old rats (Fig. $2 A$ ), whereas in both hippocampal (Fig. 2B) and cortical (Fig. 2C) slices, the effect of the drug appears to be diminished. In the latter tissues, the effects of AF-DX 116 are variable, and though the drug did 
Table 2. Parameters of ${ }^{3} \mathrm{H}-\mathrm{AF}-\mathrm{DX} 116 /$ muscarinic- $\mathrm{M}_{2}$ binding in the rat brain

\begin{tabular}{lccc}
\multicolumn{4}{c}{${ }^{3} \mathrm{H}$-AF-DX 116 binding } \\
\cline { 2 - 4 } & 3 -month-old & 9 -month-old & 27 -month-old \\
\hline Cerebral cortex & & & \\
$\quad K_{\text {max }}$ & $305 \pm 15$ & $140 \pm 8^{* * *}$ & $105 \pm 6^{* * *}$ \\
$K_{d}$ & $19 \pm 2$ & $21 \pm 4$ & $18 \pm 4$ \\
Striatum & & & \\
$\quad B_{\max }$ & $298 \pm 22$ & $220 \pm 7^{* *}$ & $198 \pm 13^{* * *}$ \\
$K_{d}$ & $24 \pm 4$ & $19 \pm 6$ & $17 \pm 2$ \\
Hippocampus & & & \\
$B_{\max }$ & $178 \pm 11$ & $127 \pm 8^{* *}$ & $78 \pm 7^{* * *}$ \\
$K_{d}$ & $23 \pm 6$ & $15 \pm 6$ & $20 \pm 4$ \\
Thalamus & $381 \pm 23$ & $184 \pm 21^{* * *}$ & $112 \pm 18^{* *}$ \\
$B_{\max }$ & $19 \pm 4$ & $21 \pm 4$ & $18 \pm 3$ \\
$K_{d}$ & & & \\
Cerebellum & $28 \pm 5$ & $22 \pm 4$ & $28 \pm 8$ \\
$B_{\max }$ & $15 \pm 3$ & $18 \pm 5$ & $13 \pm 4$ \\
$K_{d}$ & &
\end{tabular}

All binding data were derived from full saturation analysis. Homogenates were incubated in buffer containing various concentrations of ${ }^{3} \mathrm{H}-\mathrm{AF}-\mathrm{DX} 116(2-100$ $\mathrm{nM})$ for $60 \mathrm{~min}$ at $4^{\circ} \mathrm{C} . B_{\max }$ is the maximal binding capacity $\left(10^{-15} \mathrm{~mol} / \mathrm{mg}\right.$ protein), and $K_{d}$ is the apparent affinity of binding (nM). Values are the mean \pm SEM of 4-5 experiments, where each concentration was tested in triplicate.

${ }^{*}, p<0.05 ; * *, p<0.01 ;{ }^{* * *}, p<0.001$; compared to 3-month-old rats.

not significantly alter $\mathrm{ACh}$ release, modest increments in $\mathrm{ACh}$ release in the aged animals were apparent (Fig. 2, B, C). The levels of ACh released from hippocampal and cortical slices of the aged rats during $\mathbf{S} 2$ were not significantly lower than during S1 (S2:S1 range, 0.86-1.23), suggesting that the reduced effectiveness of AF-DX 116 in the aged group did not result from a time-dependent loss of tissue viability.

Muscarinic- $M$, binding sites. To assess the effects of aging on muscarinic- $\mathrm{M}_{2}$ binding site parameters, ${ }^{3} \mathrm{H}-\mathrm{AF}-\mathrm{DX} 116$ binding in homogenates of several brain regions was studied. As described in earlier studies, ${ }^{3} \mathrm{H}$-AF-DX 116 selectively labels muscarinic- $\mathbf{M}_{2}$ sites in the rat brain (Wang et al., 1987a, b; Araujo et al., 1989; Regenold et al., 1989). The results from the present study indicate that marked reductions $(28-54 \%)$ in ${ }^{3} \mathrm{H}-\mathrm{AF}-\mathrm{DX}$ 116 binding site densities can be detected in the cerebral cortex, striatum, hippocampus, and thalamus as early as 9 months (Table 2). By 27 months, ${ }^{3} \mathrm{H}-\mathrm{AF}-\mathrm{DX} 116$ binding in these brain regions is further diminished, with decreases in binding of between $35-71 \%$ (Table 2). In both groups of older rats, no significant alterations of ${ }^{3} \mathrm{H}$-AF-DX 116 binding in the cerebellum were found (Table 2). The reductions in ${ }^{3} \mathrm{H}$-AF-DX 116 binding in the older rats were clearly due to changes in the densities of sites and not the affinity of binding, because the $K_{d}$ was not altered in any of the brain areas (Table 2).

Muscarinic- $M$, binding sites. To determine whether muscarinic- $\mathrm{M}_{1}$ binding parameters are altered with age, ${ }^{3} \mathrm{H}$-pirenzepine binding was measured in several brain regions of young and old rats. As reported previously (Watson et al., 1984; Lapchak et al., 1989a, b, c), ${ }^{3} \mathrm{H}$-pirenzepine bound specifically and saturably to a single class of high-affinity sites in all brain regions studied. The results demonstrate that the effects of aging on ${ }^{3} \mathrm{H}-$ pirenzepine/muscarinic- $\mathrm{M}_{1}$ binding parameters appear to be modest (Table 3 ). For example, only small increases (11-17\%)
Table 3. ${ }^{3} \mathrm{H}$-Pirenzepine/muscarinic- $\mathrm{M}_{1}$ binding parameters in homogenates of rat brain

\begin{tabular}{lccc}
\multicolumn{5}{c}{} \\
\cline { 2 - 4 }${ }^{3}$ H-Pirenzepine binding \\
\cline { 2 - 4 } Cerebral cortex & & & \\
$\quad B_{\max }$ & $604 \pm 39$ & $542 \pm 27$ & $489 \pm 41^{*}$ \\
$K_{d}$ & $8 \pm 2$ & $10 \pm 1$ & $11 \pm 2$ \\
Striatum & & & \\
$\quad B_{\max }$ & $746 \pm 51$ & $882 \pm 67$ & $766 \pm 93$ \\
$\quad K_{d}$ & $10 \pm 2$ & $9 \pm 1$ & $8 \pm 2$ \\
Hippocampus & & & \\
$B_{\max }$ & $587 \pm 31$ & $655 \pm 58$ & $497 \pm 51$ \\
$K_{d}$ & $13 \pm 3$ & $13 \pm 2$ & $9 \pm 2$ \\
Thalamus & $346 \pm 37$ & $255 \pm 45$ & $226 \pm 40^{* *}$ \\
$B_{\max }$ & $12 \pm 3$ & $8 \pm 1$ & $6 \pm 2$ \\
$K_{d}$ & $39 \pm 7$ & $24 \pm 9$ & $30 \pm 3$ \\
Cerebellum & $6 \pm 2$ & $7 \pm 3$ & $4 \pm 1$ \\
$B_{\max }$ & & & \\
$K_{d}$ & & & \\
\hline
\end{tabular}

Brain homogenates were prepared as described in the text and incubated in buffer containing ${ }^{3} \mathrm{H}$-pirenzepine (5-100 $\mathrm{nm}$ ) for $60 \mathrm{~min}$ at $4^{\circ} \mathrm{C}, B_{\max }$ is the maximal binding capacity $\left(10^{-15} \mathrm{~mol} / \mathrm{mg}\right.$ protein), and $K_{d}$ is the apparent affinity constant (nM). Values are the mean \pm SEM of 4-5 experiments; each concentration was tested in triplicate.

${ }^{*}, p<0.05 ; * *, p<0.01$; compared to 3 -month-old group.

in the density of ${ }^{3} \mathrm{H}$-pirenzepine sites in the striatum and hippocampus of the 9- compared to the 3-month-old rats were observed, but these changes did not reach statistical significance $(p>0.10)$. In the 27 -month-old rats, these increases in ${ }^{3} \mathrm{H}$ pirenzepine binding in the striatum and hippocampus were no longer apparent; instead, significant reductions (19-33\%) in ${ }^{3} \mathrm{H}-$ pirenzepine binding in the cerebral cortex and thalamus were measured (Table 3 ). In contrast, the apparent affinity of binding of this subtype of muscarinic site was not changed with age (Table 3).

\section{Effect of aging on ACh release from rat brain slices}

To determine whether endogenous $\mathrm{ACh}$ release is attenuated with age, we measured the basal and potassium-evoked release of ACh from brain slices of 3-, 9-, and 27-month-old rats. The basal release of $\mathrm{ACh}$ was measurable in tissue slices from all brain regions of the 3 age groups (Fig. $3 A$ ). Furthermore, compared to the 3-month-old group, the basal release of ACh in most brain regions of the 9- and 27-month-old rats was not significantly altered (Fig. $3 A$ ). In striatal slices, a small reduction (14-23\%) in spontaneous ACh release was measured (Fig. 3A).

Incubation of tissue slices in Krebs medium containing a depolarizing concentration of $\mathrm{K}^{+}(25 \mathrm{~mm})$ resulted in a substantial increase in ACh release over the basal efflux (Fig. 3). However, the magnitude of this increase is smaller in the old (27-month-old) rats; $\mathrm{K}^{+}$depolarization increased $\mathrm{ACh}$ release by only $54-86 \%$, compared to $89-194 \%$ in the younger (3- and 9-month-old) rats. In the 9-month-old group, the potassiumevoked rclease of $\mathrm{ACh}$ in all tissues was not significantly different from that in the 3-month-old group (Fig. 3B). In contrast, marked reductions (25-45\%) in the potassium-evoked release of $\mathrm{ACh}$ from brain slices of 27-month-old, compared to 3-month-old rats, were evident (Fig. 3B). 


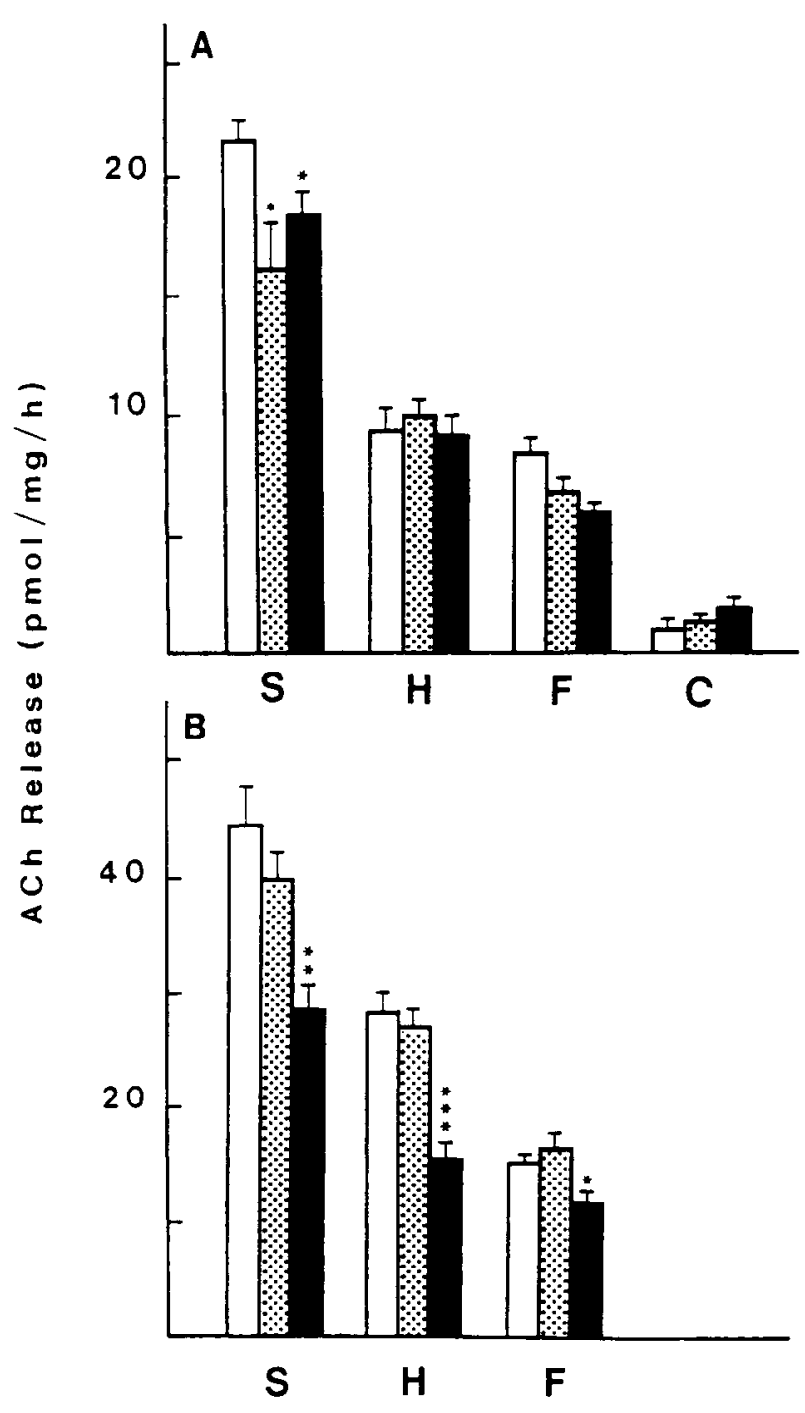

Figure 3. ACh release in brain slices of 3- (open bars), 9- (stippled bars), and 27-(solid bars) month-old rats. Striatal $(S)$, hippocampal $(H)$, frontal cortical $(F)$, and cerebellar $(C)$ slices were incubated in normalpotassium Krebs medium, and the ACh content of media was assayed for a measure of spontaneous ACh release $(A)$. In $B$, the potassiumevoked release of $\mathrm{ACh}$ was determined. Results are the mean \pm SEM of 16 experiments for each tissue in each age group. Evoked release of $\mathrm{ACh}$ was significantly decreased in all brain regions of the 27 -monthold rats $(B)$. Basal $A C h$ release was altered only in the striatum $(A) . *$, $p<0.05 ;{ }^{* *}, p<0.01 ;{ }^{* * *}, p<0.001$; compared to the 3 -month-old rats.

\section{Effect of aging on ChAT activity in various regions of the rat brain}

To determine whether brain ChAT activity is altered in normal aging, we measured ChAT activity in the striata, hippocampi, frontal cortices, and cerebella of young (3-month-old), adult (9month-old), and old (27-month-old) rats. In all brain regions studied, the activity of ChAT was not significantly different in the 9-month-old compared to the 3-month-old rats (Fig. 4). In the 27-month-old group, ChAT activity was significantly lower than in the 3-month-old rats in all brain regions except the cerebellum (Fig. 4). ChAT activity in the 27 -month-old rats was reduced by 25,48 , and $37 \%$ in the striatum, hippocampus, and frontal cortex, respectively (Fig. 4).

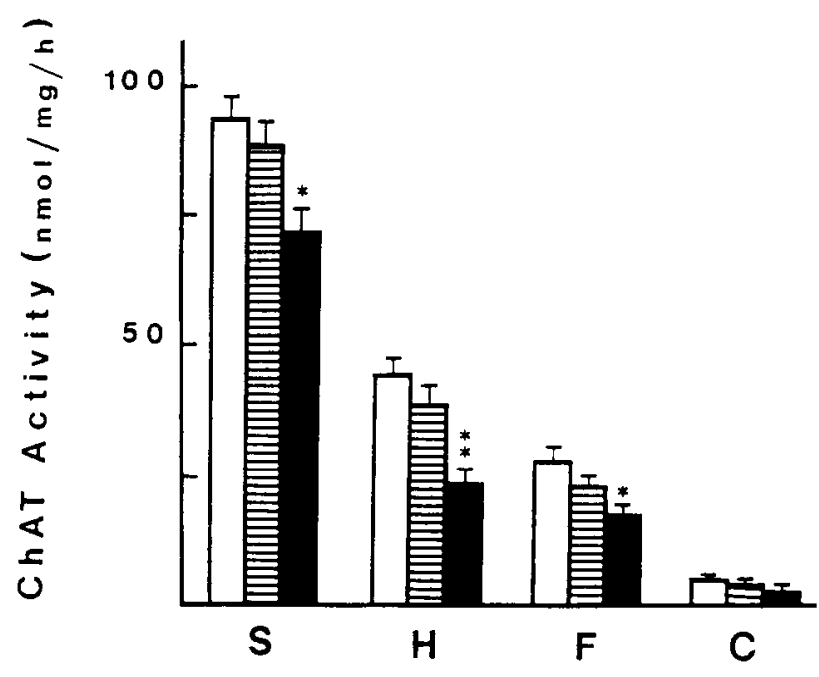

Figure 4. ChAT activity in homogenates of striatum $(S)$, hippocampus $(H)$, frontal cortex $(F)$, and cerebellum $(C)$ of 3- (open bars), 9- (hatched bars), and 27- (solid bars) month-old rats. The results are presented as $\mathrm{nmol} \mathrm{ACh}$ formed $/ \mathrm{mg}$ protein/hr and are the mean $\pm \mathrm{SEM}$ of 16 values in teach tissue for each age group. ChAT activity was significantly reduced in all tissues of aged (27-month-old) rats, with the exception of the cerebellum. ${ }^{*}, p<0.05{ }^{* *}, p<0.01$; compared to the 3 -monthold group.

\section{Discussion}

The main objective of the present work was to study the effects of aging on cholinergic autoreceptor function in various regions of the rat brain. First, we tested whether the ability of the nicotinic agonist $\mathrm{MCC}$ or the muscarinic- $\mathrm{M}_{2}$ antagonist AF-DX 116 to enhance $\mathrm{ACh}$ release from rat brain slices is altered with age. Second, we assessed whether age-related changes in cholinergic autoreceptor function may be consequent to deficits in presynaptic cholinergic markers such as ChAT activity, basal and evoked ACh release, and ${ }^{3} \mathrm{H}-\mathrm{MCC} /$ nicotinic, ${ }^{3} \mathrm{H}-\mathrm{AF}-\mathrm{DX} 116$ / muscarinic- $\mathrm{M}_{2}$ binding sites. The results show that normal aging provokes significant decrements in muscarinic, but not nicotinic, autoreceptor function in rat forebrain structures. In addition, large reductions in ChAT activity, evoked ACh release, and nicotinic and muscarinic- $\mathrm{M}_{2}$ binding sites in the aged rat forebrain were also observed. In the cerebellum, no age-related changes in presynaptic cholinergic processes were detected.

Previous studies showing that oxotremorine decreases ACh release in the hippocampus (Consolo et al., 1986) and in cortical synaptosomes (Meyer et al., 1984) of young, but not old, rats suggest that aging impairs muscarinic autoreceptor function. In agreement with this, we found that the effect of the muscarinic$\mathrm{M}_{2}$ antagonist to enhance evoked ACh release from hippocampal and cortical slices of aged rats is attenuated. This implies that minimal stimulation of muscarinic- $\mathrm{M}_{2}$ autoreceptors by an endogenous transmitter occurs in the hippocampus and cerebral cortex of aged rats. In contrast, the ability of AF-DX 116 to increase ACh release in striatal slices appeared to be enhanced in the old compared to the young rats, even though the density of muscarinic- $\mathrm{M}_{2}$ receptors is markedly reduced (see below). Thus, striatal muscarinic- $\mathrm{M}_{2}$ autoreceptors appear to be equally sensitive to activation by endogenous ACh in aged and young rats. This supports the hypothesis that long-projection cholinergic neurons of the basal forebrain-septal areas, which constitute the major cholinergic input to the cerebral cortex and hip- 
pocampus, are more susceptible to the detrimental effects of aging than interneurons, which are the primary source of cholinergic activity in the striatum (see McGeer, 1984; Strong et al., 1986; Decker, 1987).

Conflicting reports of age-related changes in the status of muscarinic cholinergic receptor sites are apparent in both human and animal literature. In Alzheimer's disease, decreases (Mash et al., 1985; Rinne et al., 1985; Reinikainen et al., 1987; Rinne, 1987; Araujo et al., 1988a) or no effect of the disease (Palacios, 1982; Bowen et al., 1983; Cross et al., 1984; Hardy et al., 1985) on cortical muscarinic binding sites have been reported. In aged rats, marked reductions $(40-50 \%)$ in the densities of muscarinic binding sites in the striatum have been frequently reported for various strains (Gilad and Gilad, 1987; Gurwitz et al., 1987; Pintor et al., 1988; Michalek et al., 1989; Waller and London, 1989). In the hippocampus and cerebral cortex of aged rats, large (Gurwitz et al., 1987; Michalek et al., 1989; Waller and London, 1989), modest (18-22\%; Lippa et al., 1980, 1981, 1985; Strong et al., 1980; Pedigo et al., 1984; London et al., 1985; Pedigo and Polk, 1985; Norman et al., 1986; Gilad and Gilad, 1987), or no decreases (Morin and Wasterlain, 1980; Briggs et al., 1982; London et al., 1985; Gilad and Gilad, 1987; Springer et al., 1987) in muscarinic binding sites have been shown.

In view of the discrepancies in the literature, we thought it necessary to test whether age-related changes in muscarinic binding sites are apparent in the population of rats used in our study. Previously, only indirect experiments that tested the competition of agonists or antagonists for ${ }^{3} \mathrm{H}$-quinuclidinyl benzilate sites had been attempted. Consequently, we directly assessed the effects of aging on brain muscarinic sites by using ${ }^{3} \mathrm{H}$-antagonists selective for muscarinic- $\mathrm{M}_{1}$ and $-\mathrm{M}_{2}$ sites. The results using ${ }^{3} \mathrm{H}$-pirenzepine and ${ }^{3} \mathrm{H}-\mathrm{AF}-\mathrm{DX} 116$ to selectively label muscarinic- $M_{1}$ and $-M_{2}$ sites, respectively, clearly demonstrate the differential effects of aging on muscarinic- $M_{1}$ and $-M_{2}$ subtypes. While the densities of muscarinic- $M_{2}$ sites were markedly reduced $(29-54 \%)$ in all forebrain structures as early as 9 months of age and further diminished (35-66\%) by 27 months, a modest decrease $(19 \%)$ in muscarinic- $M_{1}$ site density was apparent only in the cerebral cortex of the 27-month-old rats. This suggests that muscarinic- $M_{1}$ receptor function may not be detrimentally affected in the aged brain. Previous results showing that muscarinic- $\mathrm{M}_{1}$-receptor-mediated phosphoinositide hydrolysis is not altered in aged rats are consistent with this hypothesis (Surichamorn et al., 1989). Because AF-DX 116 failed to increase ACh release in the hippocampus and cerebral cortex of aged rats, the reduction in muscarinic- $\mathrm{M}_{2}$ sites in these regions appears to represent a loss of functional muscarinic autoreceptors. However, the reduced density of muscarinic- $\mathrm{M}_{2}$ sites in the striatum of aged rats is not reflected in a deficit in autoreceptor function and thus indicates that the loss of sites may represent muscarinic- $\mathrm{M}_{2}$ sites localized to noncholinergic neurons in this structure.

The existence of nicotinic autoreceptors in the hippocampus and cerebral cortex of the rat brain has been demonstrated previously (Araujo et al., 1988b; Lapchak et al., 1989a, b). The effect of the nicotinic agonist MCC to enhance ACh release from brain slices of young Sprague-Dawley rats was previously shown to be tctrodotoxin insensitive and concentration dependent, with higher concentrations $\left(>10^{-5} \mathrm{M}\right)$ of the agonist producing no effect, presumably as a result of rapid desensitization of nicotinic receptors (Araujo et al., 1988b; Lapchak et al., 1989a, b). In the present study, we show that the ability of MCC to enhance spontaneous ACh release from slices of hippocampus and cerebral cortex was only slightly altered with age. With the exception of the cerebellum, higher concentrations of MCC were required to augment $\mathrm{ACh}$ release in the aged rat brains, though the maximal increases induced by the drug were not significantly different. This suggests that a modest compromise in the sensitivity of nicotinic autoreceptors to an endogenous transmitter may occur in the aged rats. However, it is also possible that the shift in concentration of the MCC effect may be due to a small but significant loss of presynaptic nicotinic sites that normally function to regulate $\mathrm{ACh}$ release. Moreover, the increased effectiveness of $10^{-4} \mathrm{M} \mathrm{MCC}$ to enhance ACh release from cortical and cerebellar slices of the older rats suggests that nicotinic receptors in the aged animals may not desensitize as rapidly as in the young ones.

In contrast to muscarinic receptors, little is known about the status of nicotinic receptors in the aging mammalian brain. Several studies have determined that the density of nicotinic sites is diminished in the human brain in Alzheimer's disease (Flynn and Mash, 1986; Quirion et al., 1986; Shimohama et al., 1986; Whitehouse et al., 1986; Araujo et al., 1988a). However, the consequences of normal aging on nicotinic receptor sites in the human brain have not been extensively studied. Flynn and Mash (1986) and Kellar et al. (1987) have reported age-related decreases in the densities of ${ }^{3} \mathrm{H}$-nicotine and ${ }^{3} \mathrm{H}$-ACh sites, respectivcly, in postmortem tissuc from cerebral cortices of nonneurological control subjects. Prior to the present work, extensive studies of nicotinic binding sites in animal models of aging had not been reported. Our results clearly show that the densities of nicotinic binding sites, as assessed using ${ }^{3} \mathrm{H}-\mathrm{MCC}$ as ligand, are markedly reduced (34-56\%) in most forebrain areas of the aged (27-month-old) rats. No significant difference in ${ }^{3} \mathrm{H}-\mathrm{MCC}$ binding in thalamus or cerebellum of aged compared to young rats was seen. This suggests that nicotinic receptor sites in the latter structures are not as sensitive to the effects of aging as those in the cerebral cortex, striatum, and hippocampus. With the exception of the cerebral cortex, where there was a $30 \%$ decrease in the density of nicotinic sites, ${ }^{3} \mathrm{H}-\mathrm{MCC}$ binding was not different in the 9-month-old compared to the 3-month-old rats. Thus, it appears that nicotinic receptor sites are less susceptible to the effects of aging than muscarinic- $M_{2}$ sites. Furthermore, the progressive decrease in forebrain muscarinic- $\mathbf{M}_{2}$ sites with aging suggests that studying the status of these sites may be a useful diagnostic tool to determine the progression of degenerative processes associated with both normal aging and disease.

To further characterize the population of rats used in our study, we determined whether presynaptic markers of brain cholinergic neurons are altered with age. Previous studies have concentrated on measuring $\mathrm{ACh}$ content, high-affinity choline uptake, and ChAT activity in nerve terminals. The ACh content (Meek et al., 1977; Sherman et al., 1981; Consolo et al., 1986) and high-affinity choline uptake (Meyer et al., 1984; Consolo et al., 1986) in nerve terminals of the cerebral cortex, striatum, or hippocampus do not appear to be altered in the aged rodent brain. Although recent studies have attempted to characterize the release process of $\mathrm{ACh}$ in the aged rodent brain, several inconsistencies, which may be attributable to differences in the rat strains tested, as well as differences in experimental procedures, are evident from the release data. In the cerebral cortex and hippocampus, the depolarization-induced (Pedata et al., 1983, 1985; Meyer et al., 1984, 1986; Vannucchi and Pepeu, 
1987; Takei et al., 1989) and the basal (Sastry et al., 1983; Consolo et al., 1986) release of $\mathrm{ACh}$ were shown to be significantly altered with age. In contrast, Sims et al. (1982) failed to demonstrate an effect of aging on the potassium-evoked release of $\mathrm{ACh}$ in prisms of the rat cerebral cortex.

The present experiments show that there is a deficit in the potassium-evoked, but not the spontaneous, release of endogenous ACh from cortical and hippocampal slices of aged (27month-old) Long-Evans rats. These results are in agreement with previous studies that used different rat strains, experimental procedures, and assays to measure ACh (Pedata et al., 1983, 1985; Vannucchi and Pepeu, 1987; Meyer et al., 1984, 1986; Takei et al., 1989). In addition, we also observed a marked agerelated deficiency in the potassium-evoked release of $\mathrm{ACh}$ from striatal slices. In this tissue, basal $\mathrm{ACh}$ release was also altered in the aged rats, though the decrease was small (14\%) compared to that for potassium-evoked $(36 \%)$ release. Thus, the main dysfunction in cholinergic neurotransmission in the aged rat brain appears to be associated with a deficit in depolarizationrelease coupling. The age-related decrease in evoked $\mathrm{ACh}$ release may be consequent to a change in voltage-sensitive calcium influx during depolarization or to a process distal to calcium uptake. Certainly, altered calcium availability or mobilization could account for the potassium-evoked $\mathrm{ACh}$ release observed in the aged rat brains. Some support for this has been obtained from in vitro studies using synaptosomes prepared from aged rat cerebral cortex (Gibson and Peterson, 1981; Meyer et al., 1986; Pepeu et al., 1986). However, though reduced calcium influx during depolarization was shown (Gibson and Peterson, 1981; Pepeu et al., 1986), a clear relationship between this and decreased ACh release was not evident. Meyer et al. (1986) reported that aging decreases the sensitivity of synaptosomes to calcium-ionophore-induced $\mathrm{ACh}$ rclcase, suggesting that decreased transmitter release in the aged rat brain may occur subsequent to voltage-sensitive calcium entry during depolarization. Therefore, the relationship between impaired depolarization-induced calcium availability and altered $\mathrm{ACh}$ release in the aged rodent brain remains to be elucidated.

The age-related reduction in the potassium-evoked release of $\mathrm{AC} h$ in brain slices was apparent in the 27- but not 9-monthold rats. At present, it is not clear at what age the release mechanism in the rat brain is first compromised, but it has been suggested that there may be a critical period during which the ACh release process is most susceptible (Vannucchi and Pepeu, 1987). Furthermore, the larger decrement in ACh release in the striatum and hippocampus, compared to the cerebral cortex, is indicative of regional differences in the sensitivity of the transmission process to the detrimental effects of aging.

Earlier studies of ChAT activity in the aged rat brain have produced inconsistent results that may be attributable not only to scx and strain differences, but also to tissue dissections and preparations (see, e.g., Springer et al., 1987). Both reductions (Strong et al., 1980; Dravid, 1983; Gilad and Gilad, 1987; Springer et al., 1987; Pintor et al., 1988; Michalek et al., 1989; Waller and London, 1989) or no change (Meek et al., 1977; London et al., 1985; Norman et al., 1986; Strong et al., 1986) in ChAT activity in various regions of the aged rat brain have been reported. In the present study, we found that ChAT activity is significantly decreased in the striatum, hippocampus, and cortex of aged (27-month-old) rats. This effect appears to be specific to the aged rats, because no reduction in ChAT activity was observed in the 9-month-old group. Moreover, the age- rclatcd reductions in ChAT activity may be spccific to forebrain regions, because cerebellar ChAT activity was not affected.

In Alzheimer's disease, significant deficits in presynaptic cholinergic parameters such as ChAT activity, muscarinic- $\mathrm{M}_{2}$, and nicotinic receptor site densities in cortical and hippocampal structures have been reported (Bowen et al., 1976; Davies, 1979; Mash et al., 1985; Flynn and Mash, 1986; Shimohama et al., 1986; Whitehouse et al., 1986; Araujo et al., 1988a). The present study demonstrates that similar deficiencies occur in these structures in the aged rat brain. Furthermore, we show that the deficit in muscarinic- $\mathrm{M}_{2}$ receptor sites in aged animals likely represents a loss of functional muscarinic autoreceptors. In addition, Pilch and Muller (1988) have demonstrated that muscarinic receptor plasticity appears to be lost in aged animals. Therefore, attempts to ameliorate memory impairments associated with the cholinergic deficit in these structures in Alzheimer's disease (see Bartus ct al., 1982) by increasing in vivo ACh relcase with muscarinic- $\mathrm{M}_{2}$ antagonists may be a difficult endeavor. Conversely, the sensitivity of nicotinic autoreceptors in the rat cerebral cortex and hippocampus appears to be only modestly altered with age, suggesting that enhancement of ACh release by activating nicotinic autoreceptors with agonists may be useful in the treatment of Alzheimer's disease. Preliminary evidence from clinical studies has demonstrated that administration of nicotine either intravenously (Newhouse et al., 1988; Sunderland et al., 1988) or by cigarette smoking (Revell, 1988) to patients suffering from Alzheimer's disease appears to improve performance on some memory tasks.

\section{References}

Abood LG, Grassi S (1986) ${ }^{3} \mathrm{H}-$ Methylcarbamylcholine, a new radioligand for studying brain nicotinic receptors. Biochem Pharmacol 35 : $4199-4202$

Araujo DM, Lapchak PA, Robitaille Y, Gauthier S, Quirion R (1988a) Differential alteration of various cholinergic markers in cortical and subcortical regions of human brain in Alzheimer's disease. $\mathbf{J}$ Neurochem 50:1914-1923.

Araujo DM, Lapchak PA, Collier B, Quirion R (1988b) Characterization of ${ }^{3} \mathrm{H}-\mathrm{N}$-methylcarbamylcholine binding sites and effect of $\mathrm{N}$-methylcarbamylcholine on acetylcholine release in rat brain. J Neurochem 51:292-299.

Araujo DM, Lapchak PA, Regenold W, Quirion R (1989) Characterization of ${ }^{3} \mathrm{H}-\mathrm{AF}-\mathrm{DX} 116$ binding sites in the rat brain: evidence for heterogeneity of muscarinic- $M_{2}$ receptor sites. Synapse 4:106-114.

Bartus RT, Dean RL III, Beer B, Lippa AS (1982) The cholinergic hypothesis of geriatric memory dysfunction. Science 217:408-417.

Boksa P, Quirion $\mathrm{R}$ (1987) ${ }^{3} \mathrm{H}$-methylcarbamylcholine, a new radioligand specific for nicotinic acetylcholine receptors in brain. Eur J Pharmacol 139:323-333.

Bowen DM, Smith CB, White P, Davison AN (1976) Neurotransmitter-related enzymes and indices of hypoxia in senile dementia and other abiotrophies. Brain 99:459-496.

Bowen DM, Allen SJ, Benton JS, Goodhart MJ, Haan EA, Palmer AM, Sims NR, Smith CCT, Spillane JA, Esiri MM, Neary D, Snowdon S, Wilcock GK, Davison AN (1983) Biochemical assessment of serotonergic and cholinergic dysfunction and cerebral atrophy in Alzheimer's disease. J Neurochem 41:266-272.

Briggs RS, Petersen MM, Cook PJ (1982) Muscarinic agonist receptor subtypes in aging rat brain. Neurobiol Aging 3:259-261.

Candy JM, Perry EK, Perry RH, Court JA, Oakley AE, Edwardson JA (1986) The current status of the cortical cholinergic system in Alzheimer's disease and Parkinson's disease. In: Progress in brain research, Vol. 70 (Swaab DF, Fliers E, Mirmiram M, Van Gool WA, Van Haaren F, eds), pp 105-132. London: Elsevier.

Consolo S, Wang J-X, Fiorentini F, Vezzani A, Ladinsky H (1986) In vivo and in vitro studies on the regulation of cholinergic neurotransmission in striatum, hippocampus and cortex of aged rats. Brain Res 374:212-218.

Cross AJ, Crow TJ, Johnson JA, Perry EK, Perry RH, Blessed G, Tom- 
linson B (1984) Studies on the neurotransmitter receptor systems in neocortex and hippocampus in senile dementia of the Alzheimer type. J Neurol Sci 64:109-117.

Davies P (1979) Neurotransmitter-related enzymes in senile dementia of the Alzheimer type. Brain Res 171:319-327.

Decker MW (1987) The effects of aging on hippocampal and cortical projections of the forebrain cholinergic system. Brain Res 12:423438

Dravid AR (1983) Deficits in cholinergic enzymes and muscarinic receptors in the hippocampus and striatum of senescent rats: effects of chronic hydergine treatment. Arch Int Pharmacodyn Ther 264: 195-202.

Flynn DD, Mash DC (1986) Characterization of L- ${ }^{3} \mathrm{H}$-nicotine binding in human cerebral cortex: comparison between Alzheimer's disease and the normal. J Neurochem 47:1948-1954.

Fonnum F (1969a) Isolation of choline esters from aqueous solutions by extraction with sodium tetraphenylboron in organic solvents. Biochem J 113:291-298.

Fonnum F (1969b) Radiochemical microassays for the determination of choline acetyltransferase and acetylcholinesterase activities. Biochem J 115:465-472.

Gibson G, Peterson C (1981) Aging decreases oxidative metabolism and the release and synthesis of acetylcholine. J Neurochem 37:978984

Gilad GM, Gilad VH (1987) Age-related reductions in brain cholinergic and dopaminergic indices in two rat strains differing in longevity. Brain Res 408:247-250.

Goldberg AM, McCaman RE (1973) The determination of picomole amounts of acetylcholine in mammalian brain. J Neurochem 20 $1-8$.

Gurwitz D, Egozi Y, Henis YI, Kloog Y, Sokolovsky M (1987) Agonist and antagonist binding to rat brain muscarinic receptors: influence of aging. Neurobiol Aging 8:115-122.

Hardy J, Adolfson R, Alfuzoff I, Bucht G, Marcusson J, Nyberg P, Perdahl E, Wester P, Winblad B (1985) Transmitter deficits in Alzheimer's disease. Neurochem Int 7:545-563.

Kellar KJ, Whitehouse PJ, Martino-Barrows AM, Marcus K, Price DL (1987) Muscarinic and nicotinic cholinergic binding sites in Alzheimer's disease cerebral cortex. Brain Res 436:62-68.

Lapchak PA, Araujo DM, Quirion R, Collier B (1989a) Effect of chronic nicotine treatment on nicotinic autoreceptor function and ${ }^{3} \mathrm{H}$-methylcarbamylcholine binding sites in the rat brain. J Neurochem 52 483-491

Lapchak PA, Araujo DM, Quirion R, Collier B (1989b) Presynaptic cholinergic mechanisms in the rat cerebellum: evidence for nicotinic, but not muscarinic autoreceptors. J Neurochem 53:1843-1851.

Lapchak PA, Araujo DM, Quirion R, Collier B (1989c) Binding sites for ${ }^{3} \mathrm{H}-\mathrm{AF}-\mathrm{DX} 116$ and effect of AF-DX 116 on endogenous acetylcholine release from rat brain slices. Brain Res 496:285-294.

Lippa AS, Pelham RW, Beer B, Critchett DJ, Dean RL, Bartus RT (1980) Brain cholinergic dysfunction and memory in aged rats. Neurobiol Aging 1:13-19.

Lippa AS, Critchett DJ, Elhert F, Yamamura HI, Enna SJ, Bartus RT (1981) Age-related alterations in neurotransmitter receptors: an electrophysiological and biochemical analysis. Neurobiol Aging 2:3-8.

Lippa AS, Loullis CC, Rotrosen J, Cordasco DM, Critchett DJ, Joseph JA (1985) Conformational changes in muscarinic receptors may produce diminished cholinergic neurotransmission and memory deficits in aged rats. Neurobiol Aging 6:317-323.

London ED, Waller SB, Ellis AT, Ingram DK (1985) Effects of intermittent feeding on neurochemical markers in aging rat brain. Neurobiol Aging 6:100-104.

Lowry OH, Rosebrough NJ, Farr AL, Randall RJ (1951) Protein measurements with the Folin phenol reagent. J Biol Chem 193:165175.

Mash DC, Flynn DD, Potter LT (1985) Loss of $\mathrm{M}_{2}$ muscarine receptors in the cerebral cortex in Alzheimer's disease and experimental cholinergic denervation. Science 228:1115-1117.

McGeer PL (1984) Aging, Alzheimer's disease, and the cholinergic system. Can J Physiol Pharmacol 62:741-754.

Meek JL, Bertilsson L, Cheney DL, Zsilla G, Costa E (1977) Aginginduced changes in acetylcholine and serotonin content of discrete brain nuclei. J Gerontol 32:129-131

Meyer EM, St Onge E, Crews FT (1984) Effects of aging on rat cortical presynaptic cholinergic processes. Neurobiol Aging 5:315-317.

Mcyer EM, Crews FT, Otcro DH, Larsen K (1986) $\Lambda$ ging decreases the sensitivity of rat cortical synaptosomes to calcium ionophoreinduced acetylcholine release. J Neurochem 47:1244-1 246.

Michalek H, Fortuna S, Pintor A (1989) Age-related differences in brain choline acetyltransferase, cholinesterases and muscarinic receptor sites in two strains of rats. Neurobiol Aging 10:143-148.

Morin AM, Wasterlain CG (1980) Aging and rat brain muscarinic receptors as measured by quinuclidinyl benzilate binding. Neurochem Res 5:301-308.

Munson PJ, Rodbard D (1980) LIGAND: a versatile computcrizcd approach for characterization of ligand-binding systems. Anal Biochem 107:220-239.

Newhouse PA, Sunderland T, Tariot PN, Blumhardt CL, Weingartner $\mathrm{H}$, Mellow A, Murphy DL (1988) Intravenous nicotine in Alzheimer's disease: a pilot study. Psychopharmacology 95:171-175.

Norman AB, Blaker SN, Thal L, Creese I (1986) Effects of aging and cholinergic deafferentation on putative muscarinic cholinergic receptor subtypes in rat cerebral cortex. Neurosci Lett 70:289-294.

Palacios JM (1982) Autoradiographic localization of muscarinic cholinergic receptors in the hippocampus of patients with senile dementia. Brain Res 243:173-175.

Pedata F, Slavikova J, Kotas A, Pepeu G (1983) Acetylcholine release from rat cortical slices during postnatal development and aging. Neurobiol Aging 4:31-35.

Pedata F, Giovanelli L, Spignoli M, Giovannini MG, Pepeu G (1985) Phosphatidylserine increases acetylcholine release from cortical slices in aged rats. Neurobiol Aging 6:337-339.

Pedigo NW Jr, Polk DM (1985) Reduced muscarinic receptor plasticity in frontal cortex of aged rats after chronic administration of cholinergic drugs. Life Sci 37:1443-1449.

Pedigo NW Jr, Minor D, Krumrei TN (1984) Cholinergic drug effects and brain muscarinic receptor binding in aged rats. Neurobiol Aging 5:227-233.

Pepeu G, Pedata F, Giovanelli L (1986) Effects of aging on acetylcholine release and calcium uptake in rat cerebral cortex. In: Neuroendocrine systems and aging (Vezzadini P, Facchini A, Labo G, eds), pp 141-146. Rome, Italy: Eurage.

Pilch H, Muller WE (1988) Chronic treatment with choline or scopolamine indicates the presence of muscarinic cholinergic plasticity in the frontal cortex of young but not of aged mice. J Neural Transm 71:39-43.

Pintor A, Fortuna S, Volpe MT, Michalek H (1988) Muscarinic receptor plasticity in the brain of senescent rats: down-regulation after repeated administration of diisopropyl fluorophosphate. Life Sci 42: $2113-2121$.

Quirion R, Martel IC, Robitaille Y, Etienne P, Wood P, Nair NPV. Gauthier S (1986) Neurotransmitter and receptor deficits in senile dementia of the Alzheimer type. Can J Neurol Sci 13:503-510.

Regenold W, Araujo DM, Quirion R (1989) Quantitative autoradiographic distribution of ${ }^{3} \mathrm{H}-\mathrm{AF}-\mathrm{DX} 116$ muscarinic- $\mathrm{M}_{2}$ receptor binding sites in rat brain. Synapse 4:115-125.

Reinikainen KJ, Riekkinen PJ, Halonen T, Laakso M (1987) Decreased muscarinic receptor binding in cerebral cortex and hippocampus in Alzheimer's disease. Life Sci 41:453-461.

Revell AD (1988) Smoking and performance: a puff-by-puff analysis. Psychopharmacology 96:563-565.

Rinne JO (1987) Muscarinic and dopaminergic receptors in the aging human brain. Brain Res 404:162-168.

Rinne JO, Laakso K, Lonnberg P, Molsa P, Paljarvi L, Rinne JK, Sako E, Rinne UK (1985) Brain muscarinic receptors in senile dementia Brain Res 336:19-25.

Sastry BVR, Janson VE, Jaiswal N, Tayeb OS (1983) Changes in enzymes of the cholinergic system and acetylcholine release in the cerebral cortex of aging male Fischer rats. Pharmacology 26:61-72.

Sherman KA, Kuster JE, Dean DL, Bartus RT, Friedman E (1981) Presynaptic cholinergic mechanisms in brain of aged rats with memory impairments. Neurobiol Aging 2:99-104.

Shimohama S, Taniguchi T, Fujiwara M, Kameyama M (1986) Changes in nicotinic and muscarinic cholinergic receptors in Alzheimer-type dementia. J Neurochem 46:288-293.

Sims NR, Marek KL, Bowen DM, Davison AN (1982) Production of ${ }^{14} \mathrm{C}$-acetylcholine and ${ }^{14} \mathrm{C}$-carbon dioxide from $\mathrm{U}-{ }^{14} \mathrm{C}$-glucose in tissue prisms from aging rat brain. $\mathrm{J}$ Neurochem $26: 127-139$.

Springer IE, Tayrien MW, Loy R (1987) Regional analysis of agerelated changes in the cholinergic system of the hippocampal formation and basal forebrain of the rat. Brain Res 407:180-184.

Strong R, Hicks P, Hsu L, Bartus RT, Enna SJ (1980) Age-related 
altcrations in the rodent brain cholinergic system and behavior. Neurobiol Aging 1:59-63.

Strong R, Rehwaldt C, Wood WG (1986) Intraregional variations in the effect of aging on high affinity choline uptake, choline acetyltransferase and muscarinic cholinergic receptors in rat neostriatum. Exp Gerontol 21:177-186.

Sunderland T, Tariot PN, Newhouse PA (1988) Differential responsivity of mood, behavior and cognition to cholinergic agents in elderly neuropsychiatric populations. Brain Res Rev 13:371-389.

Surichamorn W, Kim ON, Lee NH, Lai WS, El-Fakahany EE (1988) Effects of aging on the interaction of quinuclidinyl benzilate, $N$-methylscopolamine, pirenzepine, and gallamine with brain muscarinic receptors. Neurochem Res 13:1183-1191.

Surichamorn W, Abdallah EAM, El-Fakahany EE (1989) Aging does not alter brain muscarinic receptor-mediated phosphoinositide hydrolysis and its inhibition by phorbol esters, tetrodotoxin and receptor desensitization. J Pharmacol Exp Ther 251:543-549.

Takei N, Nihonmatsu I, Kawamura H (1989) Age-related decline of acetylcholine release evoked by depolarizing stimulation. Neurosci Lett 101:182-186.

Tuček S (1978) Choline acetyltransferase. In: Acetylcholine synthesis in neurons (Tucek S, Koelle GB, eds), pp 3-32. London: Chapman and Hall.

Vannucchi MG, Pepeu G (1987) Effect of phosphatidylserine on acetylcholine release and content in contical slices from aging rats. Neurobiol Aging 8:403-407.

Waller SB, London ED (1989) Choline acetyltransferase activity and muscarinic binding in brain regions of aging Fischer-344 rats. Neurochem Int 14:483-490.

Wang JX, Yamamura HI, Wang W, Roeske WR (1987a) Differential regulation of $M_{2}$ muscarinic receptors by guanine nucleotides in rat cerebral cortical and cardiac membranes. Eur J Pharmacol 139:357358.

Wang JX, Roeske WR, Gulya K, Wang W, Yamamura HI (1987b) ${ }^{3} \mathrm{H}-\mathrm{AF}-\mathrm{DX} 116$ labels subsets of muscarinic cholinergic receptors in rat brain and heart. Life Sci 41:1751-1760.

Watson M, Vickroy TW, Roeske WR, Yamamura HI (1984) Subclassification of muscarinic receptors based upon the selective antagonist pirenzepine. Trends Pharmacol Sci 5:9-11.

Whitehouse PJ, Martino AM, Antuono PG, Lowenstein PR, Coyle JT, Price DL, Kellar KJ (1986) Nicotinic acetylcholine binding sites in Alzheimer's disease. Brain Res 371:146-151. 